Towards a Political Aesthetics of Cinema 



\title{
Towards a Political Aesthetics of Cinema
}

\author{
The Outside of Film
}

\author{
Sulgi Lie
}

Translated by Daniel Fairfax 
Originally published as: Die Außenseite des Films. Zur politischen Filmästhetik, Sulgi Lie. Diaphanes, Zürich-Berlin, 2012

(C) 2012 Diaphanes, Zürich-Berlin. All rights reserved.

Cover illustration: Jack Nicholson in The Shining (1980). Directed by Stanley Kubrick.

(c) Warner Bros / Collection Christophel / ArenaPAL

Cover design: Kok Korpershoek

Lay-out: Crius Group, Hulshout

$\begin{array}{ll}\text { ISBN } & 9789462983632 \\ \text { e-ISBN } & 9789048533985 \\ \text { DOI } & 10.5117 / 9789462983632 \\ \text { NUR } & 670\end{array}$

(C) S. Lie / Amsterdam University Press B.V., Amsterdam 2020

All rights reserved. Without limiting the rights under copyright reserved above, no part of this book may be reproduced, stored in or introduced into a retrieval system, or transmitted, in any form or by any means (electronic, mechanical, photocopying, recording or otherwise) without the written permission of both the copyright owner and the author of the book. 